\title{
Upaya Guru Dalam Membina Sikap Sosial Siswa
}

\author{
Zulkarnain, Maria Montessori \\ Program Studi Pendidikan Pancasila dan Kewarganegaraan \\ Universitas Negeri Padang \\ E-mail: zulkarnaineldest1@gmail.com
}

\begin{abstract}
ABSTRAK
Guru disekolah tidak hanya dituntut untuk memberikan materi pembelajaran saja melainkan guru juga dituntut untuk membina karakter dan sikap siswa, termasuk dalam membimbing dan membina sikap sosial siswa di sekolah. Sikap sosial siswa di sekolah perlu dikembangkan dalam hal saling menghormati dan menghargai, saling tolong-menolong, kerja sama, serta peduli terhadap orang lain. Penelitian ini bertujuan untuk melihat dan mengungkapkan bagaimana pembinaan sikap sosial siswa di SMP Negeri 5 Koto XI Tarusan. Jenis penelitian ini adalah penelitian kualitatif dengan menggunakan metode studi kasus. Informan pada penelitian ini ditentukan dengan cara Porposiv Sampling. Jenis datanya adalah data primer dan data sekunder dikumpulkan melalui observasi, wawancara, dan juga studi dokumentasi. Uji keabsahan data dilakukan dengan cara teknik Triangulasi. Analisis data yang digunakan yaitu Reduksi data, penyajian data, dan menarik kesimpulan. Hasil penelitian menunjukan bahwa sikap sosial siswa di SMP Negeri 5 Koto XI Tarusan masih kurang baik karena masih ada siswa yang tidak menghormati guru, berkata kasar, suka mengejek teman, tidak peduli dengan sesama. Untuk itu diperlukan upaya-upaya yang dilakukan guru dalam membina sikap sosial siswa. Upaya yang dilakukan guru di SMP Negeri 5 Koto XI Tarusan diantaranya dengan cara memberikan nasehat, memberikan sanksi atau hukuman, memberikan motivasi, melalui metode pembiasaan, pengertian, dan memberikan pembinaan dengan menggunakan model.
\end{abstract}

Kata Kunci: Upaya Guru, Sikap Sosial Siswa, Pembinaan

\section{ABSTRACT}

Teachers in schools are not only required to provide learning material but teachers are also required to foster students' character and attitudes, including in guiding and fostering social attitudes of students at school. Social attitudes of students in schools need to be developed in terms of mutual respect and respect, mutual help, cooperation, and care for others. This study aims to see and reveal how the social attitudes of students in the Middle School 5 Koto XI Tarusan. This type of research is qualitative research using the case study method. The informants in this study were determined by Porposiv Sampling. The type of data is primary data and secondary data collected through observation, interviews, and also documentation studies. Data validity test is done by using Triangulation technique. Analysis of the data used is data reduction, data presentation, and drawing conclusions. The results showed that the social attitudes of students at SMP Negeri 5 Koto XI Tarusan are still not 
good because there are still students who do not respect the teacher, say harshly, like to tease friends, do not care about others. For this reason, efforts are needed by the teacher to foster students' social attitudes. Efforts made by teachers at SMP Negeri 5 Koto XI Tarusan include by giving advice, giving sanctions or punishment, providing motivation, through methods of habituation, understanding, and providing coaching using models.

Keywords : Teacher's Efforts, Students' Social Attitudes

This work is licensed under the Creative Commons Attribution-ShareAlike 4.0 International License. @2019 by author and Universitas Negeri Padang.

\section{PENDAHULUAN}

Sejak lahir manusia membutuhkan pergaulan dengan orang lain dan perhatian dari seorang ibu untuk memenuhi kebutuhan biologisnya, makan, minum dan sebagainya (Gerungan, 1988). Pembinaan sikap sosial adalah suatu proses pembaharuan atau penyempurnaan, pengarahan, pemberian bantuan dalam menghadapi dan memecahkan masalah-masalah sosial seperti masalah pertemanan, pergaulan bebas, perkelahian antar kelompok teman sebaya, konflik sosial antar teman sebaya, masalah-masalah yang dapat meresahkan masyarakat, penyesuaian diri dalam bersosialisasi dan mengatasi masalah lainnya yang berhubngan dengan sosial. Pembinaan adalah usaha yang dilakukan secara sistematik dan terarah dalam rangka mengadakan perubahan individu oleh pembina untuk mencapai tujuan yang telah di tentukan (Hasan, 1995). Oleh karena itu sangatlah penting dilaksanakan pembinaan oleh guru disekolah, sebagaimana pembinaan sikap sosial siswa bertujuan membantu siswa mengatasi kesulitannya dalam bidang sosial. Menurut Undang-undang Nomor 14 Tahun 2005 Tentang Guru dan Dosen yang mana guru adalah pendidik profesional dengan tugas utama mendidik, mengajar, membimbing, mengarahkan, melatih, menilai, dan mengevaluasi peserta didik pada pendidikan anak usia dini jalur pendidikan formal, pendidikan dasar, dan pendidikan menengah. Pembinaan sikap sosial disekolah juga memiliki manfaat bagi siswa dalam membangun hubungan sosial baik yang sesuai pada norma dan aturan yang berlaku, selain itu juga sebagai pembantu dalam masalah bagi remaja yang memiliki masalah sosial, serta membantu mengarahkan siswa untuk mencari jati diri yang baik. Dikatakan bahwa setiap orang tidak dapat mengukur sikap secara langsung, maka sikap yang dapat diukur adalah sikap yang tampak, sikap yang tampak itu adalah perilaku (Walgito, 2003). Sikap sosial ditandai dengan bagaimana sikap atau tingkah laku individu dalam lingkungannya. Sikap individu dapat berupa, interaksi individu dengan individu atau kelompok, dilihat dari cara berbicara, menyapa, menghargai atau menghormati orang lain, tolongmenulong, patuh kepada aturan, serta tanggu jawab.

Sikap merupakan pembawaan yang dapat dipelajari dan dapat dipengaruhi perilaku seseorang terhadap benda, kejadian-kejadian, atau makhluk hidup lainnya (Dahar 
2011). Sikap sosial dapat terjadi akibat dari pengaruh lingkungan, keluarga, sekolah serta kebiasaan yang dilakukan dengan berulang-ulang (Gunarsa, 1991).. Apabia individu memiliki sikap sosial yang baik maka dia akan memiliki perilaku sosial yang baik pula baik dalam keluarga, pergaulan, sekolah, maupun dalam masyarakat. Hal ini dikarenakan adanya hubungan erat antara sikap dan perilaku. Kehidupan manusia memerlukan perilaku sosial yang melekat dalam dirinya. Perilaku sosial terdiri dari perilaku sosial dalam lingkungan keluarga dan perilaku sosial dalam lingkungan masyarakat. Perilaku sosial tersebut terdiri dari rasa kasih sayang terhadap sesama, menumbuhkan rasa aman terhadap sesama, toleransi, menghargai, menghormati orang lain, memiliki rasa tolong-menolong, dan peduli terhadap sesama (Nisrima, 2016). Dari karakteristik sikap sosial tersebut, apabila dimiliki oleh individu, maka dapat menjamin sikap sosial yang baik dan menciptakan hubungan baik atara individu dengan individu lainnya atau individu dengan kelompok, serta lingkungan keluarga maupun lingkungan masyarakat.

Guru sangat berperan penting dalam membentuk sikap, perilaku, serta karakter siswa, hal itu dilakukan guru dengan berinteraksi secara langsung dengan siswa pada saat pembelajaran maupun diluar pembelajaran (Sanjaya, 2015). Guru dituntut bukan hanya memberikan materi dalam pembelajaran, akan tetapi juga bertanggung jawab terhadap pembinaan moral dan sikap siswa yang sesuai dengan nilai, dan norma yang ada dalam masyarakat, sehingga dapat membentuk generasi muda yang memiliki sikap sosial yang baik serta bertanggung jawab bagi agama, bangsa, dan negara.

Tetapi menurut pengamatan peniliti di SMP Negeri 5 Koto XI Tarusan dilihat dari bagaimana pembinaan sikap sosial siswa, terlebih dahulu dilahat bagaimana sikap sosial guru-guru di sekolah, yang mana guru yang akan memberikan pembinaan oleh karena itu seorang guru harus juga memiliki sikap sosila yang baik supaya dapat mencerminkan kepada peserta didiknya. Dilihat dari kenyataannya berdasarkan wawancara dengan seorang guru PPKn di SMP N 5 Tarusan yang bernama Risbi Januarna, mangatakan bahwa guruguru di SMPN 5 Koto XI Tarusan sudah memiliki sikap sosial yang baik dimana terlihat semua guru-guru mampu menjalin kekeluargaan dan tidak berkelompok-kelompok. Sikap sosial yang baik dilihat dari rasa kekeluargaan, apabila salah satu guru yang mendapat musibah/sakit atau keluarganya meninggal dunia maka semua guru SMPN 5 Koto XI Tausan pergi walaupun itu diluar kota. Dan yang peneliti alami, guru-guru SMPN 5 Koto XI Tarusan juga tidak membeda-bedakan mahasiswa PLK dengan guru lain dalam hal seperti mengajak untuk duduk bersama atau saling membaur, apabila jam istirahat berlangsung guru-guru disana selalu makan bersama dan peneliti melihat guru-guru disana selalu berbagi antara guru yang satu dengan yang lainnya. Dilihat dari tindakan yang dilakukan oleh sekolah dalam pembinaan sikap sosial disekolah sperti penerapan budaya bersalaman setiap pagi atau berjumpa, setelah selesai upacara bendera pada hari senin dan setelah kultum pada hari jumat baik antara 
siswa dengan guru maupun guru dengan guru lainnya. Sedangkan dilihat dari keadaan siswa masih banyak siswa yang kurang baik dalam sikap sosial, seperti dalam kasus Bully yang dilakukan oleh siswa dan juga suka melanggar aturan sekolah, dan sampai ada juga melawan kepada guru.

\section{METODE PENELITIAN}

Penelitian ini menggunakan metode penelitian kualitatif dengan metode deskriptif, yaitu suatu jenis penelitian yang berusaha menggambarkan, menuturkan, dan menafsirkan suatu fenomenal yang sedang terjadi dimasa sekarang (Sugiyono, 2005). Penelitian kualitatif adalah suatu proses penelitian yang dilakukan secara wajar dan natural sesuai dengan kondisi objek apa yang ada dilapangan tanpa ada manipulasi. Dalam hal ini penelitian dilakukan untuk mendeskripsikan tentang pembinaan sikap sosial siswa di SMP Negeri 5 Tarusan. Oleh karena itu peneliti menggunakan jenis penelitian kualitatif dengan metode deskriptif, dengan alasan supaya dapat mendeskripsikan bentuk-bentuk perilaku siswa atau sikap sosial siswa dan bagaimana pembinaannya di sekolah.

Jenis data dalam penelitian ini dapat dikelompokan menjadi dua jenis yaitu data primer dan data sekunder. Data primer adalah data yang diperoleh peneliti langsung dari sumber asli. Dalam penelitian ini yang menjadi sumber data penelitian adalah kepala sekolah, wakil kepala sekolah, guru PPKn, dan siswa di SMP Negeri 5 Tarusan.

\section{HASIL DAN PEMBAHASAN}

Volume 2 No. 42019

Dari hasil penelitian yang telah peneliti lakukan maka peneliti mencoba melakukan pembahasan dengan mengkaitkan apa yang terjadi dalam kehidupan nyata di sekolah dengan teori yang ada. Dalam hal ini peneliti membahas bagaimana gambaran sikap sosial siswa dalam kehidupan sekolah sampai upaya yang dilakukan oleh guru dalam membina sikap sosial siswa.

Pembinaan perilaku sosial adalah suatu usaha yang dilakukan secara sistematik untuk membentuk dan merubah perilaku dalam suatu lingkungan bersama menjadi perilaku yang lebih baik serta dapat menjalankan aktivitas sosial dalam kehidupan sehari-hari. Sebagaimana menurut Undang-undang Nomor 14 Tahun 2005 Tentang Guru dan Dosen yang mana guru adalah pendidik profesional dengan tugas utama mendidik, mengajar, membimbing, mengarahkan, melatih, menilai, dan mengevaluasi peserta didik. Selama melakukan penelitin, peneliti melihat bahwa sikap sosial siswa sudah sudah cukup baik. Siswa sudah bisa untuk saling menghargai dan menghormati, saling tolong menolong, dan peduli terhadaporang lain. Namun masih ada juga beberapa siswa yang belummemiliki sikap sosial yang baik seperti masih ada siswa yang melawan pada guru, berkelahi sama teman, dan suka mengejek. Guru sebagai tenaga pendidik terus melakukan berbagai upaya agar sikap sosial siswa menjadilebioh baik. Upaya yang dilakukan guru sudah bermacam mulai dari memberi terguran, memberikan sangsi, dan juga memberikan motifasi agar siswa dapat 
memahami keberadaannya sebagai makhluk sosial.

Sikap sosial merupakan interaksi dikalangan manusia; interaksi adalah komunikasi dengan manusia lain, hubungan yang menimbulkan perasaan sosial yaitu perasaan yang mengikat individu dengan sesama manusia, perasaan hidup bermasyarakat seperti saling tolong menolong, saling memberi, simpati, antipasti, rasa setia kawan, dan lainnya (Zulkifli, 2006). Dengan hal itu siswa diharapkan dapat memiliki sikap saling menghormati, tolong menolong, saling memberi, simpati, antisipasi, dan lainnya.

Dalam membina sikap sosial ini terlihat bahwa guru sebagai pendidik sudah menjalankan perannya dengan baik. Sudah menjadi tugas guru dalam mendidik siswa agar dapat menjadi pribadi yang cerdas dan memiliki sikap yang baik dalam lingkungan sekolah dan juga masyarakat. Adapun upaya yang dilakukan oleh guru dalam membina sikap sosial adalah dengan memberikan pengarahan, nasehat, teguran, sanksi, dan motivasi kepada siswa agar mau berperilaku yang disiplin dan bertingkah laku baik terhadap semua orang melalui metode pembiasaan, pengertian, serta membina dengan menggunakan model.

Selama penelitian, peneliti melihat bahwa tanggung jawab sosial siswa telah terwujud cukup baik. Siswa sudah menerapkan kedisiplinan sesuai peraturan di sekolah, melaksanakan kerja sama dengan baik dalam piket kelas maupun dalam kelompok belajar, dan peduli terhadap lingkungan dengan menjaga lingkungan agar terlihat bersih. Meskipun masih ada siswa yang belum melaksanakan dengan baik seperti masih ada juga siswa yang belum melaksanakannya dengan baik seperti masih ada juga siswa yang terlambat datang ke sekolah, tidak mematuhi peraturan sekolah, dan tidak menjaga lingkungan sekolah dengan baik, tetapi guru terus melakukan upaya agar peserta didiknya mampu berubah menjadi lebih baik, dan memiliki kehidupan yang cerdas. Jadi, dalam mewujudkan kehidupan siswa yang lebih baik, mampu melaksanakan tanggung jawab yang diberikan maka sangat penting bagi guru dalam memberikan pembinaan kepada siswa.

\section{KESIMPULAN}

Guru adalah orang yang bertanggung jawab mencerdaskan kehidupan peserta didik. Jadi, dalam mewujudkan kehidupan siswa yang lebih baik, mampu melaksanakan tanggung jawab yang diberikan maka sangat penting bagi guru dalam memberikan pembinaan kepada siswa.

Guru memiliki peran yang sangat penting dalam pendidikan, terutama dalam membentuk sikap dan karakter siswa yang cerdas dan memiliki perilaku baik. Dalam penelitian ini guru telah menjalankan perannya dengan baik sebagai pendidik seperti mengajar, membimbing, membina, dan memberikan motivasi kepada siswa. Hal ini bertujuan agar siswa memiliki sikap sosial yang baik di kehidupan bermasyarakat dan bernegara.

Sikap sosial siswa yang ada diatas tidak terlepas dari upaya yang dilakukan guru sebagai pendidik. Adapun upaya yang dilakukan oleh guru dalam membina sikap sosial adalah dengan memberikan pengarahan, nasehat, teguran, sanksi, 
dan motivasi kepada siswa agar mau berperilaku yang disiplin dan bertingkah laku baik terhadap semua orang melalui metode pembiasaan, pengertian, serta membina dengan menggunakan model.

\section{DAFTAR PUSTAKA}

Dahar, R. W. (2011). Teori-teori belajar dan pembelajaran. Jakarta: Erlangga,

Gerungan, W. A. (1988). Psikologi Sosial, Bandung: Eresco,

Gunarsa, S. D. (1991). Psikologi praktis: anak, remaja dan keluarga. BPK Gunung Mulia.

Hasan, Langglung. (1995). Manusia dan pendidikan. Jakarta: PT. Rineka Cipta.

Nisrima, S., Yunus, M., \& Hayati, E. (2016). Pembinaan Perilaku Sosial Remaja Penghuni Yayasan Islam Media Kasih Kota Banda Aceh. Jurnal Ilmiah Mahasiswa Pendidikan Kewarganegaraan, 1(1).

Sanjaya, W. (2015). Perencanaan dan desain sistem pembelajaran. Kencana.

Sugiyono. (2005). Memahami penelitian kualitatif. Bandung: Alfabeta.

Walgito, Bimo (2003). Psikologi Sosial (Suatu Pengantar). Yogyakarta: Andi Offset.

Zulkifli, L. (2006). Psikologi Perkembangan. Bandung: Rosdakarya. 